\title{
TYÖELÄMÄ KOULUTUKSEN KUMPPANINA
}

\author{
Johannes Koroma
}

\section{Teollisuuden ja työnantajien näkökulmasta osaaminen ja ammattitaito ovat ydinkysymyksiä. Siksi koulutus kiinnostaa kaikissa sen vaiheissa, peruskoulusta ja opettajakoulutuksesta aikuisen uusiutumiskykyyn.}

$\mathrm{S}$ uomessa avautuu alkaneen vuosikymmenen aikana kaikkiaan noin 700000 työpaikkaa. Vuositasolla se tarkoittaa, että tässä maassa tarvitaan vuosittain noin 70000 uutta työntekijää täyttämään arvioitua työllisyyden nettolisäystarvetta ja korvaamaan eläkkeelle siirtyviä.

On selvää, että tämä laskelma on tarkkuudessaan vaan suuntaa antava ja siihen vaikuttavat ratkaisevasti muutokset sekä tuottavuuden kasvussa että eläkkeelle siirtymisen keski-iässä.

E niten huolta on julkisuudessa kannettu siitä, viittääkö Suomessa omaa väestöä täyttämään vuosikymmenen aikana avautuvat työpaikat vai onko turvauduttava aktiiviseen ulkomaalaispolitiikkaan työvoiman tarpeen tyydyttämiseksi. Alhainen syntyvyys, väestön ikääntyminen ja liian varhainen eläköityminen ovat antaneet aiheen tähän huoleen.

Y htä tärkeää on kuitenkin selvittää, riittääkö koulutusjärjestelmämme nykykapasiteetti täyttämään arvioitua tarvetta. Ongelmia se tulee aiheuttamaan varsin monilla toimialoilla eikä vain tietoteollisuudessa vaan esimerkiksi metallialalla, kuljetuksissa ja liikenteessä sekä rakennusaloilla. Luetteloa voisi jatkaa myös paperi- ja kemianteollisuudella sekä liikenteellä.

$\mathrm{O}$ saaminen on valittu keskeiseksi strategiseksi menestystekijäksi Suomessa, mutta myös laajalti Euroopassa ja koko maailmassa. Sen ni- meen vannotaan, puhuttiinpa sitten taloudellisesta kasvusta, kilpailukyvystä tai työttömyyden vähentämisestä. Tuorein osaamista ja koulutusta koskeva raportti on Sitran Suomi 2015 -ohjelma, jonka laatimiseen itsekin aktiivisesti osallistuin.

Raportin laatijoiden yhteinen käsitys oli, että Suomen menestys rakentuu monille vahvuuksille ja ylivoimatekijöille. Kaiken perusta on osaaminen ja sen saavuttamisessa koulutuksella on keskeinen asema. Korkean osaamisen avulla varmistamme, että meillä on riittävästi inhimillistä pääomaa taloudellisen ja sosiaalisen menestyksen turvaamiseksi. Se edellyttää konsensusta

1 Tietoyhteiskunnan merkityksestä

1 Kattavasta koulutusjärjestelmästä

1 Omaleimaisesta kansallisesta kulttuurista ja laadukkaista kulttuuripalveluista

1 Selkeistä yhteiskuntanormeista ja työhön liittyvistä arvoista sekä

1 Vahvasta yhteiskunnan moraalista.

Suomalaisessa yhteiskunnassa on samalla myös paljon kehitettävää ja uhkatekijöitä, joihin pitää kiinnittää erityistä huomiota. Näitä ovat $\mathrm{mm}$.

1 Väestön ikääntyminen ja uhkaava työvoimapula

1 Koulutuksesta puuttuva joustavuus, jatkuvuus ja yksilöllisyys

1 Maahanmuuttajien taitojen hyödyntäminen

1 Asenteet ja ennakkoluulot monikulttuurisuutta vastaan. 
Tämä osoittaa, että koulutus ja osaaminen eivät ole suinkaan menestyksen ja työllistymisen ainoita ehtoja, mutta välttämättömiä ne ovat. Koulutus ei ole kuitenkaan aina vastannut odotetulla tavalla niihin tarpeisiin, joita yritykset ja muu työelämä asettavat. Meillä on työttömyyttä, mutta samanaikainen työvoimapula.

$\mathrm{T}$ ulevaisuuden työmarkkinoilla vaaditaan monialaisuutta ja moniuraisuutta. Koulutus on yhä enemmän sellaisten ominaisuuksien hankkimista, jotka mahdollistavat työskentelyn eri aloilla ja eri ammateissa sekä uran uudelleensuuntaamisen joustavasti koko ihmiselämän ajan. Sen tulee antaa osaamista myös ongelmien ratkaisemiseen eikä vain kaavamaiseen opitun toistamiseen.

Tämän perusteella päädyimme myös siihen johtopäätökseen, että Suomen koulutusjärjestelmä on ennakkoluulottomasti arvioitava ja ennakoivasti uudistettava, jotta suomalainen yhteiskunta säilyttää asemansa osaamiskilpailussa, sekä, että koulutuksen tehokkuutta tulisi lisätä oppimisjärjestelmiä kehittämällä, uusinta osaamista hyödyntämällä, koulutusaikaa jaksottamalla, koulutustukien kannustavuutta lisäämällä ja tutkintoja monipuolistamalla sekä koulun aloittamisaikaa varhentamalla. Rohkenenpa liittää tähän myös näkemykseni siitä, että tässä onnistuminen edellyttää opettajien motivaation parantamista nostamalla opetustehtävissä olevien arvostusta yhteiskunnassa ja tarkistamalla palkkausta tehtävien vaativuuden edellyttämällä tavalla.

\section{Teollisuus tarvitsee osaajia}

Nämä näkökohdat ovat kansallisen strategian toteuttamisen kannalta merkittäviä, mutta erityisen tärkeitä ne ovat teollisuudelle, jonka työvoiman tarve ja ammattitaidon vaatimukset ovat jatkuvasti lisääntymässä. Teollisuus ja rakennustoiminta ovat tasaisesti lisänneet työvoiman kysyntää koko laman jälkeisen kuuden vuoden ajan. Kaikkiaan nämä alat työllistävät arviolta enemmän suomalaisia kuin ennen 90-luvun lamaa. Tällöin olen laskenut mukaan sen osuuden liike-elämää palvelevien yritysten työvoimasta, joka on joko ulkoistamisen tai toimialarationalisoinnin tuloksena siirtynyt teollisuudesta esimerkiksi sellaisiin palveluihin kuin rahoitus, tietotekniikka, huolto ja kunnossapito, vartiointi, työpaikkaruokailu, kuljetukset jne.

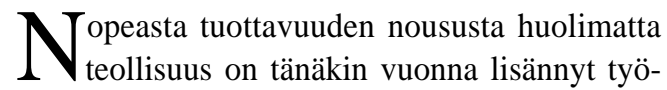
voimaa ja sen seurauksena joutunut yhä useammin tekemiseen ammattitaitoisen työvoiman puutteen kanssa. Kaikki merkit viittaavat siihen, että myös tulevina vuosina työvoimantarve lisääntyy.

Suurin kysyntä suuntautuu nuoriin koulutettuihin, joilla on hyvä ammattitaito, tietotekniikan osaaminen ja kielitaito. Pahin puute tulee olemaan Uudellamaalla ja muissa kasvukeskuksissa.

TT:n kyselyjen mukaan eniten puutetta on tunnetusti tietotekniikan sekä elektroniikka-alan ammattitaitoisista työntekijöistä, mutta myös rakennusalan ja metalli- ja kemianteollisuuden ammattilaisista kuten asentajista, levysepistä, luokkahitsaajista ja puusepistä. Vaatimukset koulutuksen osalta ovat kasvaneet ja puolet kysynnästä kohdistuukin lähivuosina yliopisto- ja ammattikorkeakoulutasoisen koulutuksen saaneisiin, toinen puoli toisen asteen ammattikouluista valmistuneisiin.

Valitettavasti tekniikka ei kiinnosta riittävästi nuoria. Toisen asteen koulutuksessa on ollut vaikea saada kaikkia aloituspaikkoja täyteen. Ja vaikka saataisiinkin, niin teollisuuden kannalta keskeisille aloille tuleva oppilasaines peruskoulun päästötodistuksen mukaan on selvästi huonompi kuin esimerkiksi palvelualoilla. 
$\mathrm{T}_{\mathrm{n}}$ ämä tosiasia pakottaa yritykset etsimään syitä myös omasta toiminnastaan. Mielikuva teollisista ammateista on edelleen vanhakantainen ja vaikka sitä on johdonmukaisesti pyritty nykyaikaistamaan jo vuosikymmenen ajan, ei siinä ole onnistuttu. On etsittävä uusia keinoja ja jatkettava tiedon antamista. Ehkäpä osansa mielikuvaan ovat jättäneet uutiset työriidoista, irtisanomisista ja taloudellista vaikeuksista kuluneen vuosikymmenen aikana. Varmaan myös palkkausjärjestelmien monipuolistaminen, kansainvälistyminen, monipuolisuus, luovuus ja mahdollisuus itsensä toteuttamiseen on jäänyt näissä tehtävissä vähemmälle.

Eräs syy teknillisen alan koulutuksen huonoon vetovoimaan on myös matemaattis-luonnontieteellisen opetuksen riittämättömyys peruskoulussa ja lukiossa. Pitkän matematiikan, fysiikan ja kemian kirjoittajia on liian vähän. Opetusministeriön LUMA-talkoissa on tehty hyvää työtä, mutta tulokset näkyvät kovin hitaasti.

$\mathrm{S}$ itran raportista ilmenee, että yrityksen rekryointitarpeiden uudet painotukset vaativat nopeaa reagointia ja suurta joustavuutta sekä hallinnolta että oppilaitoksilta. Opetusministeriötä onkin kiittäminen siitä, että se lisäsi runsaasti tietoteollisuuden tarvitsemia koulutus- ja tutkimuspanostuksia lähivuosiksi. Tämä rohkea ja kauaskantoinen päätös turvaa osaltaan työvoimapulasta kärsivien alojen ammattitaitoisen henkilöstön saannin. Samalla se vahvistaa merkittävästi kasvualojen investointiedellytyksiä Suomessa.

Myös tietoteollisuuden osaajapulan odotetaan helpottuvan lähivuosina. Vuonna 2005 arvioidaan alalle valmistuvien määrän olevan jo noin 7 000, kun vuonna 1998 valmistuneita oli vain noin 1500 .

\section{Matematiikka pakolliseksi yo-aineeksi}

$\mathrm{T}_{\mathrm{n}}$ T on jo vuosia kannanotoissaan esittänyt, että matematiikka tulisi tehdä pakolliseksi aineeksi ylioppilaskirjoituksissa. Vähintä mitä voidaan vaatia on, että kaikki kirjoittavat ainakin lyhyen matematiikan. Reaalikoe tulisi jakaa kahteen osaa, joista toinen olisi matemaattis-luonnontieteellinen kokonaisuus ja toinen humanistis-yhteiskuntatieteisiin painottuva kokonaisuus. Kokeen suorittamisessa, kuten kaikessa oppimisessa tulisi myös tietotekniikan mahdollisuuksia käyttää hyväksi nykyistä paremmin.

Peruskoulun tuntimäärää tulisi lisätä ja kiinnittää huomiota opettajakoulutukseen. Huippujen lisäksi suurempien oppilasmäärien kiinnostus matemaattis-luonnontieteellisiin aineisiin saattaisi kasvaa myös sillä, että opetuksen kokeellisuutta lisätään. Jos learning by doing -periaate puree ammatillisessa peruskoulutuksessa, miksei se auttaisi myös yleissivistävissä opinnoissa.

\section{Teknologiakasvatus peruskouluun ja lukioon}

Tehokkain keino matemaattis-luonnontieteellisen osaamisen lisäämiseksi saattaisi sittenkin olla teknologiakasvatuksen vahvistaminen. Tietotekniikan omaksumista tulisi toteuttaa ajattelemalla, että kyse on kaikille kansalaisille välttämättömästä uudesta luku- ja kirjoitustaidosta.

Teknologiakasvatuksen tavoitteena on muuttaa opetusta käytännönläheisemmäksi. Joko integroituna muihin aineisiin tai peräti uutena oppiaineena opetussuunnitelmiin otettu teknologia olisi automaattisesti käytännönläheistä. Tavoitteena voisi olla tiedon, kokemuksen ja voimavarojen soveltaminen siten, että luodaan ihmisten tarpeita vastaavia tuotteita ja prosesseja.

$\mathrm{M}^{\mathrm{i}}$ iksi huomio sitten on kiinnitettävä juuri matematiikkaan, luonnontieteisiin ja teknologiaan? Näiden aineiden uskotaan kehittävän ongelmaratkaisukykyä paremmin kuin mitkään muut oppiaineet. Suurin motiivi opetuksen kehittämiseen maailmalla on myös eri maiden huoli yhteiskuntien inhimillisen ja taloudellisen kilpailukyvyn kehittymisestä. Tämä ei kuitenkaan tarkoita, että unohdetaan hyvän yleissivistyksen, humaanisuuden, etiikan ja moraalin merkitys yhtä vähän kuin on syytä väheksyä käden taitojen kehittämistä. 


\section{Asiantuntijaryhmä työhön}

Peruskoulun ja lukion opetussuunnitelman perusteet uudistetaan lähiaikoina. Peruskoulun uusittu opetussuunnitelma otetaan käyttöön esiopetuksen toimeenpanon jälkeen asteittain lukuvuodesta 2002-2003 alkaen. Lukion vuoro tulee sen jälkeen.

Tämän valmistelutyön yhteydessä tulisi tarkastella myös teknologiakasvatuksen ottamista opetussuunnitelman perusteisiin. Sen tarpeellisuutta peruskoulussa ja lukiossa voidaan tuskin asettaa kyseenalaiseksi. Monet muut maat ovat meitä jo paljon pitemmällä. Lisäksi nuorten houkutteleminen teknillisille aloille ja tietotekniikkaan edellyttää teknologiakasvatuksen vahvistamista. Paras tapa edetä suunnittelussa olisi se, että opetusministeriö käynnistää teknologiakasvatusta koskevan hankkeen. Tälle hankkeelle asetetaan asiantuntijaryhmä, jossa teollisuuskin haluaa olla mukana.

\section{Elinikäisen oppimisen edellytykset hyvät}

$\mathrm{K}$ oulutus- ja osaamisvaranto uusiutuu sukupolvien myötä vain neljänneksen 10 vuoden aikana. Suomalaisen yhteiskunnan ja yritysten on panostettava myös aikuisväestön ammattitaidon ylläpitämiseen ja kehittämiseen.

Työmarkkinajärjestöt ovat yhteistyössä opetusviranomaisten ja poliittisten päättäjien kanssa sopineet opintovapaan periaatteista sekä perustaneet Koulutus- ja erorahaston. Tuorein esimerkki on koulutusvakuutus, jonka III-vaiheen lainsäädäntöä valmistellaan. Elinikäinen oppiminen on hyväksytty yhteiskunnassamme yleiseksi yksilön, yritysten ja yhteiskunnan kehittämisperiaatteeksi, mitä se sitten kullakin merkinneekään.

TT on esittänyt oman visionsa elinikäisestä oppimisesta "Oppia ikä kaikki” jo vuosia sitten. Työ tehtiin talkoilla TT:n, jäsenliittojen ja yritysten sekä teollisuuden eräiden oppilaitosten asiantuntijoiden yhteistyönä ja sen mukaisesti olemme pyrkineet toimimaan koulutuspoliittisessa ja muussa yhteiskunnallisessa päätöksen teossa.

Vision tavoitteena olivat

1 Muuttuva, ympäristötietoinen informaatioyhteiskunta

1 Globaali yritystoiminta

1 Teollisuuden kehitysmyönteinen imago

1 Tietoon ja taitoon perustuva työpaikka

1 Motivoitunut yksilö ja hyvä yleissivistys

1 Tieto osaamistarpeista

1 Joustavan oppimismahdollisuuden turvaaminen.

Tavoitteeseen pyritään yritysten koulutuskulttuuria kehittämällä sekä lisäämällä opetuksen ja yritystoiminnan vuorovaikutusta. Apuna oppimisessa käytetään uutta tekniikkaa.

$\mathrm{M}^{\mathrm{s}}$ onet tavoitteet visiostamme ovat toteutuneet tai toteutumassa. Oppiminen on saatu lähemmäksi työelämää. Siitä esimerkkinä ovat mm. toisen asteen ammatilliseen koulutukseen tuleva puolen vuoden työssäoppimisjakso sekä työelämälähtöiset koulutusmallit työvoimakoulutuksessa. Myös yritykset ovat ottaneet henkilöstönsä kehittämisen ja kouluttamisen tosissaan. TT:n osaamistarveselvitykset nimittäin osoittavat, että yritysten koulutuspanostukset henkilöstöönsä verrattuna maksettuihin palkkoihin kaksinkertaistuivat lamavuosista vuosituhannen loppuun mentäessä. Tänä vuonna koulutusinvestoinnit nousevat vajaaseen 3 miljardiin markkaan ja vuonna 2002 arviolta 3,5 miljardiin markkaan. Teollisuuden panostukset inhimilliseen pääomaan ovat siis kasvaneet ja edelleen kasvamassa tulevina vuosina. Tämä on välttämätöntä, sillä monissa tietointensiivisissä yrityksissä tärkein pääoma onkin "oma pää".

\section{Teollisuuden ammattikorkea- koulu ja "akateeminen op p i s o p i m u s"}

$\mathrm{O}$ sana elinikäisen oppimisen strategian käytännön toteuttamista olemme esittäneet teollisuuden ammattikorkeakoulun sekä ns. "aka- 
teemisen" oppisopimuksen kehittämistä. Kumpikaan ei ole edennyt toivotulla tavalla, vaikka ne olisivat hyvä keino työssäolevan väestön osaamistason kohottamiseksi ja niistä on hyviä kokemuksia muista maista.

Osaamisen ajan tasalla pitäminen edellyttää paitsi julkisen koulutusjärjestelmän, myös yritysten toimenpiteitä. Nykyisten panostusten lisäksi yrityksillä on halukkuutta teknisen pätevyyden nostamiseksi täydennyskoulutuksen keinoin. Esimerkiksi teollisuuden palveluksessa toimivien teknikoiden osaamista halutaan kohottaa tutkintotavoitteisesti ammattikorkeakouluinsinöörin tasolle. Tätä tehtävää varten olisi haluttu perustaa oma verkostomaisesti toimiva ammattikorkeakoulu.

Kysymys on käytännössä Espoon-Vantaan teknillisen ammattikorkeakoulun muuttamisesta teollisuuden ammattikorkeakouluksi, jossa olisi hyödynnetty myös AEL:n korkeaa teknistä osaamista sekä JTO:n ihmisten johtamiseen ja tuottavuuteen liittyvää asiantuntemusta. Tämä uudenlainen ammattikorkeakoulu olisi eräs keino lisätä nopeasti koulutettua henkilöstöä työvoimapulaa poteville aloille.

Toinen keino ratkaista nopeasti koulutusongelmia pullonkaula-aloilla olisi ns. akateemisen oppisopimuksen käynnistäminen. Ratkaisu olisi tarpeen siksi, että opettajaresurssien puute oppilaitoksissa on yhä suurempi koulutuksen toteuttamisen riski. Yrityksen innovatiivinen oppimisympäristö yhdessä korkeakoulujen opetuksen kanssa varmistaisivat niin laadukkaan lopputuloksen, jota tuskin muilla keinoin saavutettaisiin.

Molemmissa oli kysymys uudenlaisesta ratkaisusta elinikäisen oppimisen konkreettiseksi toteuttamiseksi. Lupaa näiden käynnistämiseksi opetusministeriö ei kuitenkaan vielä tähän mennessä ole antanut. Uskon kuitenkin, että jos tällainen ammattikorkeakoulu ei sovi pääkaupunkiseudulle sillä on ottajansa muualla maassa. Kiinnostusta on ilmaistu ainakin parilla taholla.

\section{Yhteiskunnalla vastuu - teollisuus auttaa}

Däävastuu yleissivistävästä ja ammatillisesta peruskoulutuksesta on julkisella vallalla. Yritysten tulee ylläpitää ja kehittää henkilöstönsä ammattitaitoa. Lisäksi jokaisella ihmisellä on vastuu omasta kehityksestään. Kukaan ei voi oppia toisen puolesta. Rahoitusvastuun tulee noudattaa yleensä samoja periaatteita. Tämän vuoksi suomalaisella yritysmaailmalla ei ole mahdollisuutta osallistua ammatillisen peruskoulutuksen rahoittamiseen. Oman henkilöstön kehittäminen on ensisijainen velvollisuus.

Yritykset voivat kuitenkin osallistua ammatillisen peruskoulutuksen vastuunkantamiseen tiivistämällä yhteistyötä alueensa oppilaitosten kanssa ja vaikuttamalla suoraan opetuksen kehittämiseen. Erityisesti yritysten vastuulla on tarjota nuorille harjoittelu- ja työssäoppimispaikkoja.

Muita mahdollisuuksia tukea oppilaitosten toimintaa ovat

1 Oppisopimusoppilaiden ottaminen

1 Kesätöiden tarjoaminen

1 Diplomitöiden, gradujen ja erilaisten päättötöiden teettäminen

1 Oppilaitosten hallintoelimiin ja neuvottelukuntiin osallistuminen

1 Oppimateriaalin valmistaminen yhteisesti

1 Opettajien teollisuuden tuntemuksen parantaminen

1 Tuntiopettajien tarjoaminen oppilaitosten käyttöön.

Yhdentyvässä maailmassa ja kovassa kansainvälisessä kilpailussa meidän on pystyttävä tuottamaan entistä parempia tuotteita entistä halvemmalla. Tämä on mahdollista vain silloin, kun oppilaitokset kouluttavat mahdollisimman hyviä ammatti-ihmisiä, tiedemiehiä ja tutkijoita. Koulutuspolitiikan on kuitenkin tuettava tätä kuten muissa kilpailijamaissamme tapahtuu. Siihen perustuu myös henkinen hyvinvointimme - kuten taiteet ja koko kulttuurielämä.

Tiedot, taidot ja osaaminen 2010 - koulutuksen ja työelämän yhteistyön uudet haasteet -seminaari 17.8.2000 Helsingissä 